\title{
Solidão na Comunhão: as lições da Vida Monástica em tempos de isolamento
}

\author{
Solitude in Communion: \\ the lessons of Monastic Life in times of isolation
}

Cristiano Holtz Peixoto

\section{Resumo}

A pandemia da COVID-19 mudou radicalmente os modos de relacionamento de todas as pessoas. Embora se percebessem traços de individualismo no comportamento humano, há pouco tempo era impensável que fosse possível, ou mesmo necessário, o mundo inteiro se isolar para evitar a rápida disseminação do coronavírus. Este artigo visa mostrar como a Vida Monástica, que tem como uma de suas características o afastamento da sociedade, tem a contribuir para a reflexão teológica do momento atual a partir de conceitos-chave praticados e refletidos há muitos séculos, a saber, a solidão e a comunhão. Longe de se distanciar de forma alienada do mundo, os monges e monjas vivem uma profunda comunhão com a humanidade, e a sabedoria multissecular vivida nos claustros pode ajudar a iluminar o presente contexto. Refletindo sobre textos antigos e novos, é possível oferecer uma ajuda concreta àqueles que vivem atualmente, de forma compulsória, um modo de vida que monges e monjas abraçaram como resposta ao chamado de Deus neste modo de vida específico.

Palavras-chave: Vida Monástica. Solidão. Comunhão. Isolamento. Pandemia. 


\begin{abstract}
The COVID-19 pandemic has radically changed the way people relate to each other. Although traces of individualism were perceived in human behavior, not long ago was unthinkable that it was possible, or even necessary, for the entire world to isolate itself to prevent the rapid spread of the coronavirus. This article aims to show how Monastic Life, which has as one of its characteristics the distancing from society, has to contribute to the theological reflection of the present moment from key concepts practiced and reflected for many centuries, namely, loneliness and communion. Far from distancing themselves alienated from the world, monks and nuns live a deep communion with humanity, and the multi-century wisdom experienced in the cloisters can help to illuminate the present context. Reflecting on old and new texts, it is possible to offer concrete help to those who currently live, in a compulsory way, a way of life that monks and nuns embraced in response to the call of God in this specific way of life.
\end{abstract}

Keywords: Monastic life. Loneliness. Communion. Isolation. Pandemic.

\title{
Introdução
}

Em uma aula enquanto me preparava para o mestrado, fui iluminado por um exemplo tão simples quanto comovente, que transformou minha concepção do que é a Teologia. Para ilustrar a importância e o papel da Teologia, o professor, lançando mão da formação profissional de alguns alunos, fez a alguns deles a mesma pergunta. Para um físico, perguntou: você vê as leis da Física nesta sala de aula? O aluno respondeu afirmativamente; a um jurista, perguntou: você vê o Direito na dinâmica da vida universitária? O aluno igualmente concordou. Então, o professor concluiu: o teólogo é - e sempre deveria ser - aquele que enxerga Deus em todas as realidades, porque acredita que todas elas vêm de Deus e manifestam, a seu modo, Sua Presença.

Eis a circunstância iluminadora que me arrebatou e tirou a trave que, até então, eu trazia diante dos meus olhos sem perceber: que a Teologia é uma ciência, mas é antes, e fundamentalmente, uma experiência comunicada de Deus (por isso Teo - logia).

Utilizo este exemplo à guisa de introdução porque, tendo sido ele o evento iluminador da minha "conversão teológica", foi o que logo me ocorreu 
ao ver o tema desta edição da revista Pesquisas em Teologia: "Teologia e Pandemia”. É possível enxergar Deus no contexto da pandemia? Indubitavelmente é possível. No caso do presente artigo, a pergunta que se põe é outra: qual o contributo que a Vida Monástica tem a dar para ajudar a clarear a visão de Deus em meio a um momento tão difícil pelo qual passamos em nível global? Seu isolamento característico tem algo a dizer, ou talvez a ensinar, à nossa geração tão acelerada e ativa?

Creio firmemente que não somente é possível, mas especialmente benéfico, dar voz à vida recolhida e silenciosa, para com ela enxergar algo da beleza de Deus em meio ao caos no qual estamos inseridos e para o qual por vezes nos faltam respostas. Utilizaremos, como chave de leitura, os conceitos de solidão e comunhão, em perspectiva simbiótica: a Vida Monástica tem a nos ensinar como viver a solidão na comunhão.

\section{Diferenças entre o contexto atual e a Vida Monástica}

A razão mais evidente para apresentar a Vida Monástica como instância eclesial capaz de ajudar a enfrentar os difíceis tempos atuais é o fato de que, nos mosteiros, se vive objetiva e livremente, por escolha, um modo de vida muito semelhante ao que o mundo inteiro se vê constrangido a praticar.

Contudo, ao avaliar superficialmente o contexto vital antes da pandemia, percebemos que, na verdade, as medidas sanitárias e políticas adotadas não fizeram mais que evidenciar uma chaga há algum tempo vivenciada pela humanidade, embora não evidente: todos vivíamos um isolamento coletivo. É suficiente ler considerações como as de Z. Bauman quando, falando sobre os "tempos líquidos", exemplifica como típico o "padrão do acampamento":

O lugar está aberto a quem quer que venha com seu trailer e dinheiro suficiente para o aluguel; os hóspedes vêm e vão; nenhum deles presta muita atenção a como o lugar é gerido, desde que haja espaço suficiente para estacionar o trailer, as tomadas elétricas e encanamentos estejam em ordem e os donos dos trailers vizinhos não façam muito barulho e mantenham baixo o som de suas TVs portáteis e aparelhos de som depois de escurecer. [...] Os motoristas trazem para o acampamento suas próprias casas. [...] Ocasionalmente podem reivindicar melhores serviços; $[\ldots]$ mas nunca lhes ocorreria questionar e negociar a filosofia administrativa do lugar, e muito menos assumir a responsabilidade pelo gerenciamento do mesmo. ${ }^{1}$

${ }^{1}$ BAUMAN, Z., Modernidade líquida, p. 35. 
Nesse sentido, a pandemia, mais que a causa real (o contágio do coronavírus), "contagiou" o mundo inteiro, simultaneamente, com o "vírus" da lucidez sobre sua própria condição: da ilusão de onipotência - mascarada pela falsa ideia de felicidade, conquistada pelo poder aquisitivo e pelo status social, e veiculada pela mídia como combustível para embalar o consumo -, chegamos à percepção real de nossa vulnerabilidade e de nossa incapacidade de prever e construir o futuro somente a partir de nós mesmos, sem confiar em Deus e sem manifestar solidariedade, amparando os nossos semelhantes - sobretudo os menos favorecidos - e cuidando da natureza, para preservar condições de vida em nosso planeta. Instaurou-se, assim, uma profunda crise, quando, por força das circunstâncias, muitos se viram destituídos da "maquiagem"2 dos estereótipos de vida feliz e bem sucedida, e de controle. Como observou H. Nouwen:

As pessoas [...] estão conscientes de que os mesmos poderes que nos permitem criar novos estilos de vida também carregam o potencial para a autodestruição. [...] Para tais pessoas o problema não é que o futuro reserva um novo perigo, como uma guerra nuclear, mas que pode não haver futuro algum. ${ }^{3}$

Na Vida Monástica, por outro lado, não se sentiu tanto o impacto do isolamento forçado que a pandemia impôs ao mundo. Naturalmente, não é possível afirmar que não houve nenhum impacto - sobretudo no que diz respeito à presença e participação dos fiéis na vida litúrgica e na ação pastoral, bem como o reflexo no declínio econômico e a consequente adaptação ao contexto de crise, tanto para manutenção da comunidade quanto no tocante às questões administrativas e trabalhistas. - Mas, em termos específicos, a vida intramonasterial não sofreu alterações drásticas: as orações, as práticas ascéticas, o ritmo de trabalho das comunidades monásticas continuaram acontecendo, ainda que levando em consideração as alterações mencionadas.

Isso se deve ao fato de se tratar de uma vida menos acelerada que a praticada e vivida por quase todo mundo. Em um mosteiro, como se sabe, a vida é regida pelo primado de Deus: a oração norteia e define as demais atividades. Além disso, monges e monjas não vivem na ociosidade, pois, como ensina a Regra de São Bento, "são verdadeiros monges se vivem do trabalho de suas mãos". ${ }^{4}$ E, embora muitos, inclusive dentro da Igreja, a depreciem ou julguem como ultrapassada e incongruente com os tempos nos quais vivemos,

\footnotetext{
${ }^{2}$ FRANCISCO, PP., Vida após a pandemia, p. 21.

${ }^{3}$ NOUWEN, H. J. M., O curador ferido, p. 18.21.

${ }^{4} \mathrm{RB} 48,8$.
} 
sua prática não é a de isolamento do mundo enquanto subtração, tornando-se alheia a ele, mas, de certa forma, de uma profunda comunhão com o mesmo, seja pela intercessão por suas necessidades, seja pela união solidária a todos os homens no trabalho e na vida de pobreza. Pode-se dizer que se trata de uma vida que foge do mundo, no sentido que lhe confere o Evangelho de João, ${ }^{5}$ por amor a ele, para colaborar na obra de sua redenção:

O mundo é inimigo de Deus, mas Deus não é inimigo do mundo. [...] Cristo veio ao mundo para salvar os pecadores. Mas enquanto o mundo não for redimido, os cristãos não podem identificar-se com ele. As preocupações pelas coisas do mundo afastam de Deus. [...] Os cristãos, como Jesus, estão no mundo e em relação ao mundo têm uma missão: se vencem o mundo é por amor e unicamente por amor. ${ }^{6}$

\section{Vida Monástica: entre história e teologia}

Essas razões ajudam a compreender o valor da Vida Monástica, independentemente do tempo no qual vivemos. Contudo, existem dois argumentos que esclarecem a validade de seu modo de existência: um histórico e outro teológico.

\subsection{O argumento histórico: a experiência da ação}

Compreender a Vida Monástica como "um anacronismo sem sentido no mundo moderno" é fruto de uma ignorância histórica, dada a importância que este modo de vida teve para a construção da sociedade ocidental tal como a conhecemos.

É certo afirmar que um primeiro movimento característico da Vida Monástica desde sempre é o afastamento da sociedade, ou, em linguagem técnica, fuga mundi ("fuga do mundo"). Qual seu significado? Se o monge é aquele que busca a Deus para se tornar um só com Ele (o termo deriva do grego monachós, cuja raiz é monós, um), não é possível fazer tal movimento sem separar-se do mundo. Tal separação, é, segundo A. Roberts, feita em dois níveis: pessoal $/$ psicológico e social/eclesial. ${ }^{8} \mathrm{O}$ afastamento que o monge empreende não tem como razão o ódio ao mundo ou à vida, mas um profundo

\footnotetext{
${ }^{5}$ MCKENZIE, J. L., Mundo, p. 638.

${ }^{6}$ MCKENZIE, J. L., Mundo, p. 637-638.

${ }^{7}$ MERTON, T., Contemplação num mundo de ação, p. 240.

${ }^{8}$ ROBERTS, A., Vida Monástica, p. 81.
} 
amor a Deus, a tal ponto que o faz deixar para trás tudo que lhe é mais caro: ele descobre Deus como sua única riqueza e, por causa Dele, abre mão de tudo o mais, assim como as parábolas do tesouro e da pérola (Mt 13,44-46), ícones da Vida Religiosa em geral.

As primeiras manifestações de Vida Monástica, como se sabe, são eremíticas, nas quais o monge vive só (mais tarde é que se desenvolverá a forma cenobítica, onde os monges vivem reunidos nos mosteiros). O que vai buscar o monge no deserto? Encontrar-se com Deus, pela renúncia aos bens, pela dureza da ascese, pela oração contínua e pelo trabalho. Os monges se sustentavam com o trabalho de suas mãos. O lucro do que produziam e vendiam era utilizado para sustento pessoal e para caridade.

Como "não se pode esconder uma cidade situada sobre o monte" (Mt $5,14)$, não demorou muito para a Vida Monástica sair do anonimato. O exemplo dos homens de Deus irradiou seu esplendor no entorno de onde se encontravam, e desde então, os monges passaram a realizar visivelmente o preceito evangélico do amor incondicional a Deus e do amor ao próximo como a si mesmos. Eram buscados como mestres, como defensores dos pobres, como taumaturgos, etc. Desde então, a aparente inutilidade da Vida Monástica foi substituída pela importante ação dos monges na história.

O mais recluso dos eremitas, o mais firmemente agarrado à solidão e ao silêncio, não podia evitar que almas sofridas viessem consultá-lo. [...] "Ide e evangelizai todos os povos!" Os monges eram por demais santos para poderem furtar-se à ordem de Cristo: e assim a vida meditativa em Deus deu lugar à vida ativa por Deus. ${ }^{9}$

Se tal movimento gerou impacto enquanto ainda se tratava da vida eremítica, com muito mais razão se pode dizer do modo cenobítico, ou seja, de quando começou a se estabelecer o gênero comunitário da Vida Monástica. Pela oração, os mosteiros se tornaram centros de peregrinação, locais aos quais as pessoas sempre acorreram em busca de Deus; pelo trabalho, se tornaram modelo de construção da sociedade ocidental como a conhecemos.

O silêncio e a vida de oração dos monges levaram-nos a evangelizar a Europa, desbravando inúmeras e vastas regiões, algumas das quais ainda inóspitas. Como recorda Daniel-Rops, existiu nessa época um "vivo paradoxo que é o monge missionário - homem amigo de estar em casa e recluso por

${ }^{9}$ DANIEL-ROPS, H., A Igreja dos tempos bárbaros, p. 217. 
vocação, que sai do seu convento para correr o vasto mundo a fim de semear a Boa Nova". ${ }^{10}$

Enviados ou por iniciativa própria, sozinhos ou em grupos, os monges partiram para iniciar a obra de evangelização. Nomes como São Cesário de Arles, São Martinho de Tours, Santo Agostinho de Hipona, São Columbano, Santo Agostinho de Cantuária, São Bonifácio, São Patrício, entre outros, são exemplos eloquentes da concretização do preceito joanino: "Quem ama a Deus, ame também o seu irmão" (1Jo 4,18). Eis o ideal da "peregrinação por Cristo":

Desterraram-se voluntariamente, abandonaram sua pátria queridíssima, seu mosteiro, para praticar uma ascese mais rigorosa e um desprendimento mais total, para dedicar-se à oração com o espírito mais livre. Viver no estrangeiro como estrangeiros. ${ }^{11}$

Também a sua vida de trabalho fez com que desenvolvessem, muito cedo e de forma prática, técnicas desconhecidas para a realização de muitos serviços, como agricultura, construção, metalurgia, drenagem de pântanos, etc., sem mencionar a notabilidade que ganharam no campo da cultura:

Neles [mosteiros] se criaram escolas que atraíram inúmeros discípulos, o que permite entender sua influência civilizadora na sociedade bárbara. [...] Deste modo, o monasticismo acabou por assumir um papel de guia cultural, em realidade, alheio ao primitivo espírito da instituição. ${ }^{12}$

Em sua obra Como a Igreja Católica construiu a civilização Ocidental, T. Woods descreve como os monges participaram ativamente na construção da sociedade ocidental. ${ }^{13}$ Resumindo a importância do movimento monástico para a fundação da civilização, reconhece:

Os monges desempenharam um papel crucial no desenvolvimento da civilização ocidental. A julgar pelas práticas de ascese a que se dedicavam, dificilmente se poderia imaginar o enorme impacto que viriam a provocar no mundo exterior. Mas esse fato histórico surpreende menos quando nos lembramos das palavras de Cristo: Procurai primeiro o reino dos céus e tudo o mais vos será dado por acréscimo. ${ }^{14}$

${ }^{10}$ DANIEL-ROPS, H., A Igreja dos tempos bárbaros, p. 217.

${ }^{11}$ COLOMBÁS, G. M., La tradición benedictina, p. 491.

12 SÁENZ, A., História da Santa Igreja, p. 284.

${ }^{13}$ WOODS Jr., T. E., Como a Igreja Católica construiu a civilização Ocidental, p. 25-45.

${ }^{14}$ WOODS Jr., T. E., Como a Igreja Católica construiu a civilização Ocidental, p. 25. 


\subsection{O argumento teológico: a experiência do vazio ou do santo far niente}

Como foi possível observar, o modo histórico é suficiente para demonstrar a importância e a utilidade da Vida Monástica. Contudo, seria empobrecer seu valor reduzir o seu valor intrínseco à sua utilidade, mecanismo de defesa muito em voga entre os próprios contemplativos, como recorda Merton. ${ }^{15}$

Além disso, fugiria ao escopo deste artigo, pois se trataria de mera descrição histórica. Por isso, o argumento teológico é, sem dúvida, a justificativa mais importante para elucidar a importância da Vida Monástica. Paradoxalmente, seu valor reside em sua inutilidade. Chamo a esse estado de santo far niente. ${ }^{16}$ Mas o que isso significa?

Para compreender melhor, analisemos o discurso de T. Radcliffe em um Congresso de Abades da Ordem Beneditina:

Por que as pessoas são tão atraídas por mosteiros? A minha ideia é que os vossos mosteiros revelam Deus não por causa do que fazeis ou dizeis, mas talvez porque a vida monástica tem no seu centro um espaço, um vazio, no qual Deus se pode mostrar. [...] A minha esperança é que os mosteiros beneditinos continuem a ser lugares nos quais a glória de Deus brilha, tronos para o mistério. E isto pelo que vós não sois, pelo que vós não fazeis. ${ }^{17}$

Seu discurso se inicia perguntando: qual o maior contributo, ou a finalidade teológica da Vida Monástica? Qual a sua atualidade em um mundo repleto de ação? Ao que ele mesmo responde: é o fato de os monges não terem um "objetivo de vida", ao menos em termos práticos. É não "ter que servir para algo". E é justamente nesse vazio, quando não o protagonismo humano, que Deus habita, Se manifesta. As imagens bíblicas do trono de Deus e do sepulcro vazio são o melhor testemunho a este respeito:

A glória de Deus mostra-se sempre num espaço vazio. Quando os israelitas saíram do deserto, Deus veio com eles sentado no espaço entre as asas dos querubins, por cima do trono de misericórdia. O trono da glória era esse vazio. Era só um espaço pequeno, a largura de um palmo.

\footnotetext{
${ }^{15}$ MERTON, T., Contemplação num mundo de ação, p. 241-242.

${ }^{16}$ Em referência ao dolce far niente italiano.

${ }^{17}$ RADCLIFFE, T., Monges, Vidas Vazias e Beleza.
} 
Deus não precisa de muito espaço para mostrar a sua glória. [...] O mais autêntico trono de glória é um túmulo vazio, onde não está o corpo. ${ }^{18}$

Ainda segundo Radcliffe, uma de suas hipóteses para a existência desse "vazio" repleto da presença de Deus nos mosteiros se deve ao fato de que não existe uma atividade sequer desenvolvida pelos monges que os defina e que especifique a natureza de sua vocação:

O fato mais óbvio na vida dos monges é que não fazem nada de especial. Cultivais a terra, mas não sois lavradores. Ensinais, mas não sois professores. Podeis mesmo dirigir hospitais, ou centros de missão, mas não sois em primeiro lugar nem médicos nem missionários. Sois monges que seguem a Regra de São Bento. Não fazeis nada de especial. Os monges são geralmente pessoas muito ativas, mas a ação não é o objetivo e o propósito das vossas vidas. [...] É esta ausência de finalidade explícita que revela Deus como a finalidade secreta, oculta das vossas vidas. Deus é revelado como o centro invisível das nossas vidas quando não tentamos dar qualquer outra justificação para o que somos. ${ }^{19}$

De fato, um rápido olhar para a história, como fizemos anteriormente, revela a vasta gama de atividades com as quais os monges se envolveram e continuam a se envolver, em virtude do trabalho inerente à sua vocação. Contudo, nenhum destes trabalhos os qualifica profissionalmente - seja no campo acadêmico, científico, técnico, jurídico, etc. Quando são lembrados pelas atividades desenvolvidas, sobressai sua identidade primordial: são monges. Em sua Regra, São Bento fundamenta toda a atividade "inútil" do monge com o seguinte versículo bíblico: "Por causa Daquele que nos amou". ${ }^{20}$

Em suma, podemos dizer que o objetivo teológico da Vida Monástica é recordar ao mundo o que há de mais fundamental dentro de cada ser humano, aquilo que é irrenunciável: tudo o que fazemos e somos nos direciona para Deus. A maior razão de nossa existência é procurá-Lo e viver com Ele e Nele. Merton, concluindo sua reflexão sobre ação e contemplação, observa:

Qual a relação de tudo isso [contemplação] com a ação? Simplesmente a seguinte: aquele que tenta agir e realizar coisas para os outros ou para o mundo sem aprofundar a própria compreensão de si mesmo, sua liberdade, sua integridade e sua capacidade de amar, nada terá para dar

\footnotetext{
${ }^{18}$ RADCLIFFE, T., Monges, Vidas Vazias e Beleza.

${ }^{19}$ RADCLIFFE, T., Monges, Vidas Vazias e Beleza.

${ }^{20} \mathrm{RB} 7,39$.
} 
aos outros. [...] Estamos atravessando a maior crise da história do homem. E esta crise se situa, sobretudo, justamente no país que fez da ação um ídolo e que perdeu (ou talvez nunca tenha tido) o sentido da contemplação. ${ }^{21}$

\subsection{Os argumentos psicológico e estético: a humildade e o canto}

As reflexões trazidas até aqui certamente nos enriquecem e ajudam a perceber a "força que se manifesta na fraqueza" (1Cor 12,9) do monge. Embora tais razões bastem para justificar a relevância teológica da Vida Monástica, Radcliffe, iluminado pela reflexão teológica anterior, ainda apresenta outros dois aspectos a seu respeito, um de ordem psicológica e outro de ordem estética:

O cume da humildade é descobrir não só que não se é o centro do mundo, mas que nem mesmo se é o centro de si mesmo. $O$ vazio não existe só no centro da comunidade onde Deus habita, mas existe também no centro do meu ser. Sou uma criatura a quem Deus dá existência a cada momento. [...] No coração do meu ser não estou só. Deus está lá dando-me a existência a cada momento com o seu sopro. No centro de mim não está o eu solitário, o ego Cartesiano, mas um espaço que é preenchido por Deus. Talvez seja esta a suprema vocação do monge: mostrar a beleza desse vazio, ser, individual e comunitariamente, templo para que nele habite a glória de Deus. No coração da vida monástica está a humildade. Não a humildade acabrunhante, depressiva, dos que têm ódio a si mesmos, mas a humildade dos que se reconhecem criaturas, cuja existência é um dom. E por isso é coisa certíssima que no centro de sua vida haja canto, porque é neste canto que se manifesta o ato criador de Deus. Cantamos essa Palavra de Deus, pela qual tudo é feito. Aqui sentese uma beleza que é mais do que apenas o agradável. É a beleza que celebra o irromper da criação. ${ }^{22}$

\section{Solidão na Comunhão: as lições da Vida Monástica}

Este rico e belo modo de viver profundamente imersos em Deus e ao mesmo tempo solidamente enraizados na humanidade e no amor-serviço ao próximo, por todas as razões apresentadas, tem algo sólido a ensinar à nossa

\footnotetext{
${ }^{21}$ MERTON, T., Contemplação num mundo de ação, p. 249-250. O texto de Merton fala especificamente dos Estados Unidos. Contudo, esta realidade pode ser aplicada ao nosso mundo sem grande esforço.

${ }^{22}$ RADCLIFFE, T., Monges, Vidas Vazias e Beleza.
} 
geração, afetada pelos reflexos do isolamento pandêmico. Sua lição se resume a dois conceitos-chave de seu próprio dinamismo interno: solidão e comunhão. No entanto, apesar de tais conceitos terem sua validade específica e de haver a necessidade de um equilíbrio entre ambos, a verdadeira grande lição emerge da integração, da simbiose entre os dois, ou seja, de como viver a solidão na comunhão.

Para atingir nosso objetivo, apresentaremos primeiramente os dois conceitos e, a seguir, faremos a correlação entre eles, tal como se busca viver nos mosteiros.

\subsection{Solidão}

O motivo pelo qual o monge vive a solidão parece óbvio. Contudo, o que se deve compreender é qual o uso semântico deste termo em contexto monástico, pois certamente não é o mesmo empregado pelo senso comum. Para um monge, ser solitário não é estar isolado. Na linguagem monástica, isolamento é antônimo de solidão. O monge ama a solidão porque, nela, encontra a si mesmo e a Deus. Ou melhor, encontra a Deus dentro de si e encontra-se no Ser de Deus.

A busca da solidão não é, no entanto, um movimento espontâneo e fácil. Em uma sociedade como a hodierna - na qual se impõe a ditadura da interatividade -, optar por silenciar, por se afastar, por manter-se reservado, sempre foi um desafio para o monge, quanto mais com a revolução tecnológica e com a inerente "invasão do mundo" também dentro dos mosteiros por meio da internet. E, como se não bastassem os desafios externos, o monge ainda terá de lidar com os desafios internos, como a dispersão, o desejo de estar continuamente em contato com tudo e todos, etc. Efetivamente, a crise da sociedade hodierna em face da pandemia é a primeira luta que o monge trava ao cruzar o limiar da clausura monástica: o movimento do isolamento à solidão.

Como é possível fazer tal movimento? H. Nouwen nos dá uma valiosa pista:

Este difícil caminho é o caminho da conversão, da conversão do isolamento à solidão. Ao invés de fugir do nosso isolamento e tentar esquecê-lo ou negá-lo, temos que protegê-lo e transformá-lo em uma solidão fecunda. Para viver uma vida espiritual, devemos primeiro encontrar a coragem para entrar no deserto de nosso isolamento e transformá-lo, por esforços suaves e persistentes, em um jardim de solidão. Isso requer não apenas coragem, mas também uma forte fé. Por mais difícil que seja acreditar que o deserto seco e desolado possa render 
infinitas variedades de flores, é igualmente difícil imaginar que nosso isolamento esteja escondendo uma beleza desconhecida. ${ }^{23}$

Em primeiro lugar, trata-se de assumir nossa condição fragmentada, isolada. Somente assim poderemos iniciar o processo de cura. E, uma vez constatado e assumido como condição real da nossa existência, perceberemos a necessidade de silenciar para escutar o coração, para estar com Deus e deixar que Ele, no deserto do nosso isolamento, nos fale ao coração (Os 2,16). Esta atitude exige grande nível de maturidade, que não será conquistada se não houver uma luta sincera em nosso interior, e uma constância na oração, para aprendermos com nossas próprias chagas. Elas não são curadas nem por causa de nosso desejo nem na medida de nossas forças, mas começam a ser tocadas na medida de nossa abertura a Deus e quando tomamos consciência de que, em nossa finitude, precisamos Dele.

Um movimento tão sério não se faz sem um real isolamento físico, ao menos inicialmente. Como é possível concentrar-nos em nós mesmos, em escutar o profundo de nosso ser, em meio às agitações da vida cotidiana? Muitas pessoas têm experimentado o tempo da pandemia como uma graça especial à sua vida de oração, porque, antes, estavam tão envolvidas no frenesi da vida contemporânea que mal tinham tempo para dizer algumas orações, quanto mais parar para contemplar o mistério do Emanuel, o "Deus em nós". Ainda assim, por mais que seja necessário reservar tempo e espaço, até se criar internamente o espaço para o diálogo com Deus e consigo, não se pode atrelar a solidão à reserva física:

É provavelmente difícil, senão impossível, passar do isolamento para a solidão sem qualquer forma de afastamento de um mundo que os distrai e, portanto, é compreensível que aqueles que tentam seriamente desenvolver sua vida espiritual sintam-se atraídos por lugares e situações onde podem estar sozinhos, ou por um período limitado de tempo, ou de forma mais ou menos permanente. Mas a solidão que realmente conta é a solidão do coração; é uma qualidade ou atitude interior que não depende do isolamento físico. Ocasionalmente, esse isolamento é necessário para desenvolver essa solidão de coração, mas seria triste se considerássemos esse aspecto essencial da vida espiritual como um privilégio de monges e eremitas. ${ }^{24}$

${ }^{23}$ NOUWEN, H. J. M., Reaching Out, p. 22.

${ }^{24}$ NOUWEN, H. J. M., Reaching Out, p. 25. 
Os dois problemas que esta fixação por um espaço físico podem gerar são: em primeiro lugar, uma dependência, de forma que, se não houver silêncio ou espaço, a pessoa não consiga rezar, e acabe descontando sua frustração no meio exterior quando, na verdade, o trabalho é sempre interior. Em seguida, o risco de, como observou Nouwen, julgar que somente a Vida Contemplativa em sentido estrito ou institucionalizado é digna e louvável, como se Deus não estivesse em todo lugar e pudesse realizar Sua graça como bem Lhe aprouver. São Paulo afirma: "onde está o Espírito do Senhor, aí está a liberdade" (2Cor $3,17)$. Portanto, se cremos na onipresença de Deus, todo tempo, todo lugar, toda situação são propícios para que busquemos a Deus e nos recolhamos em solidão diante Dele.

Por fim, vale dizer que o monge escolhe a solidão não por gosto pessoal, misantropia ou timidez. É verdade que alguns tipos de temperamento ajudam a desenvolver um "comportamento silencioso". Porém, se esta fosse a referência para se definir solidão, a Vida Monástica nada teria a ensinar às pessoas de nosso tempo; no máximo seria capaz de falar algo àqueles que compartilham temperamento semelhante. A solidão monástica é um mistério, é a participação na Solidão Divina (unum Deum), é uma comunhão íntima e indissolúvel com Aquele que nos criou, é uma resposta de amor ao Deus-Amor, que prescinde de palavras e mesmo de gestos evidentes. Essa solidão transparece na serenidade com que, pouco a pouco, passamos a encarar os fatos, na sabedoria para "discernir o tempo presente" (Lc 12,56) e, dessa forma, na confiança de se entregar inteiramente nas mãos Daquele que nos ama.

\subsection{Comunhão}

O outro lado da moeda se chama comunhão. Ainda que se isole do mundo, o monge continua a ser humano. Isso o mantém intrinsecamente ligado a toda a humanidade. Logo, pode-se tranquilamente dizer-se a seu respeito o que proclama a Constituição Gaudium et Spes:

As alegrias e as esperanças, as tristezas e as angústias dos homens de hoje, sobretudo dos pobres e de todos aqueles que sofrem, são também as alegrias e as esperanças, as tristezas e as angústias dos discípulos de Cristo; e não há realidade alguma verdadeiramente humana que não encontre eco no seu coração. ${ }^{25}$

${ }^{25} \mathrm{GS} 1$. 
Se se pode afirmar algo tão belo e profundo a respeito da união do monge com toda a humanidade, quanto mais, se este for cenobita, se dirá da comunidade mais próxima, que são seus irmãos na vocação monástica.

A vida do monge cenobita é marcada pela sua pertença à comunidade. Nada é feito sem ela: rezam juntos, tomam refeição juntos, estudam juntos, argumentam soluções para a vida prática juntos, de tal forma que nem o Abade, embora "faça as vezes de Cristo no mosteiro" ${ }^{26}$ tem autonomia para suplantar uma decisão tomada pelo Capítulo Conventual (a comunidade dos irmãos professos). Portanto, é nítido que, na experiência cenobítica, a comunidade tem um valor supremo.

O perigo é manter-se nesse nível superficial de relacionamento, caindo numa espécie de comunitarismo, ou transformar o senso comunitário em uma falsa ideia de democracia, o que esvaziaria a essência da vida comunitária. Os monges não vivem em comunidade para suprir necessidades ou carências de qualquer ordem. Eles são reunidos por Deus que os chama à mesma vocação, independentemente dos afetos ou dissabores que possam ter ou desenvolver entre si. Efetivamente, na Vida Monástica, todo monge pode dizer à sua comunidade e a cada irmão em particular: "O amor de Cristo nos uniu". Por isso, o conceito-chave que define uma comunidade monástica é comunhão.

Assim como vimos que a solidão do monge é participação na Solidão do Deus Uno, a comunhão fraterna é participação na comunhão do Deus Trino. Os monges são chamados a ser imagens fiéis da Unidade-Trindade divina por meio dessas duas chaves de compreensão da sua vida.

Comunhão, nesse sentido, não é estar juntos o tempo inteiro, falar com todos, gostar de todos. É reverenciar cada irmão e a comunidade inteira como "raça eleita, sacerdócio real, nação santa, povo de Sua particular propriedade, a fim de proclamar as excelências Daquele que os chamou das trevas para a Sua luz maravilhosa" (1Pd 2,9). O monge deve, naturalmente, ser agente de comunhão com sua participação ativa na vida da comunidade, especialmente venerando e acolhendo obedientemente a ação divina naqueles que foram escolhidos para integrá-la. Por isso, os votos professados pelo monge (Estabilidade na comunidade, Conversão de Vida segundo o modo de vida monástico e Obediência) são a pedra de toque da Vida Monástica.

Em resumo, se para toda a Igreja é fundamental aprender a viver em comunhão, para o monge é vital. Não existe Vida Monástica sem comunhão. Mas, assim como a solidão, para gerar espaço de comunhão também é preciso

${ }^{26} \mathrm{RB} 2,2$. 
fazer um grande movimento na alma. E este movimento é justamente o da articulação das duas faces da moeda.

\subsection{Solidão na Comunhão}

Nouwen nos ajudou a compreender que, para alcançarmos a solidão, é preciso assumir nosso isolamento existencial e, a partir daí, aprendermos junto do Senhor a curá-lo. De forma semelhante, para alcançarmos a comunhão verdadeira é preciso vivê-la a partir da solidão.

Como é possível viver a solidão na comunhão? Considerando que a verdadeira comunhão não é comunitarismo, não se trata apenas de estar juntos fisicamente ou de forjar sentimentos artificiais que justifiquem a unidade. $\mathrm{O}$ maior erro que a humanidade cometeu foi acreditar que, para gerar comunhão, bastava estar juntos. Antes da pandemia, vivíamos um profundo isolamento existencial, embora cercado de pessoas. Por isso não o percebíamos, pois estávamos anestesiados. Quando, porém, as circunstâncias nos forçaram a cortar os falsos laços de convivência que nos mantinham seguros dentro de nossos castelos existenciais, sob o pretexto de sermos bem relacionados (o número de "amizades", seguidores, likes e tweets das redes sociais que o digam), toda a estrutura ruiu, de modo que muitas pessoas ficaram deprimidas e com medo do futuro ao constatar que seu castelo era de areia.

Em que consiste, então, a verdadeira comunhão? Em um estado que começa no interior de cada um de nós, capaz de nos dar plena consciência de nossos limites e de nossas possibilidades, e que, por conseguinte, nos faz enxergar o outro em sua realidade, tal como ele é. Consiste em aprender a amar de verdade, superando a questão meramente afetiva, a reconhecer o Divino presente no outro, a amar nele a Divindade invisível aos olhos. O irmão não é o inferno, como supunha Sartre, nem é o céu, porque ele é somente uma criatura, como nós. Ele é um instrumento da glória de Deus, um espelho no qual vemos nossa própria imagem e a imagem de Deus. No irmão, descobrimos onde Deus mora, e somos convidados a permanecer com Ele (Jo 1,38-39).

Por isso, o empenho para alcançar a solidão é não somente um profundo gesto de caridade e de crescimento na comunhão fraterna, mas uma condição sine qua non para que a verdadeira comunhão fraterna seja possível. Assim é no mosteiro, assim pode ser na vida de cada pessoa. $\mathrm{Na}$ verdade, quanto mais solitários formos - no sentido que refletimos -, tanto mais seremos agentes de comunhão com nossos semelhantes. Nouwen observa: 
Sem a solidão do coração, a intimidade da amizade, do casamento e da vida comunitária não podem ser criativas. Sem a solidão do coração, nossos relacionamentos com os outros facilmente se tornam carentes e gananciosos, pegajosos e apegados, dependentes e sentimentais, exploradores e parasitas, porque sem a solidão do coração não podemos sentir os outros como diferentes de nós, mas apenas como pessoas que podem ser usadas para a satisfação de nossas próprias necessidades, muitas vezes ocultas. ${ }^{27}$

De forma surpreendente, a pandemia, além da percepção de que o comunitarismo individualista no qual vivíamos era ineficaz, nos trouxe também a oportunidade de perceber que estamos muito mais próximos uns dos outros do que poderíamos supor, como recordou o Papa Francisco:

Demo-nos conta de estar todos no mesmo barco, todos frágeis e desorientados, mas ao mesmo tempo importantes e necessários: todos chamados a remar juntos, todos carecidos de mútuo encorajamento. [...] Também nós nos apercebemos de que não podemos seguir adiante cada qual por conta própria, mas só o conseguiremos juntos. ${ }^{28}$

Que seja esta a grande lição de toda a presente situação: da solidão que podemos conquistar a partir do isolamento pandêmico, nos tornarmos, cada vez mais e de modo mais profundo, agentes de comunhão com todas as pessoas e com toda a criação.

\section{Conclusão}

O monge é fundamentalmente aquele que busca a Deus. Nada que é humano lhe é estranho. Portanto, a Vida Monástica tem, certamente, algo a contribuir com a presente situação, e sua contribuição é profundamente teo lógica, no sentido mais literal da palavra: olhando para a realidade que é impregnada da presença de Deus, falar de Deus às pessoas, com seu exemplo, e falar das pessoas a Deus, com suas orações.

Consideremos ainda a carta circular que o Abade Geral dos Cistercienses, Dom Mauro Lepori, enviou, neste tempo da pandemia, a todas as comunidades de sua Ordem. Esta carta, porém, pode ser considerada patrimônio teológico da humanidade, em virtude de sua relevância.

${ }^{27}$ NOUWEN, H. J. M., Reaching Out, p. 30.

${ }^{28}$ FRANCISCO, PP., Vida após a pandemia, p. 19. 
Dom Mauro parte de uma pergunta muito semelhante a que nos propomos a responder neste artigo: que contribuição tem a Vida Monástica a oferecer à sociedade neste tempo de desolação e angústia? Sem dúvida alguma, a primeira contribuição, como bem recorda, é a de passarmos por esta situação dando-lhe um sentido. Ele começa, portanto, descrevendo a realidade:

$\mathrm{O}$ verdadeiro drama que a sociedade está vivendo atualmente não é tanto ou apenas a pandemia, mas as suas consequências em nossa existência cotidiana. O mundo parou. [...] Esta parada imposta pelo contágio e pelas autoridades é apresentada e vivida como um mal necessário. De fato, o homem contemporâneo já não sabe mais parar. Ele só para se for detido. $[\ldots]$ Nem mesmo nas férias se para realmente. ${ }^{29}$

De fato, com exceção daqueles que sofreram diretamente pelo contágio, grande parte das pessoas sofreu apenas com o isolamento, com o tédio de ter que parar sua rotina desgastante, mas que preenchia sua vida. Parar é sinônimo de se tornar inútil. Como bem notado por ele, mesmo nosso lazer é cheio de atividades. É possível, então, tirar alguma lição do mal necessário da parada compulsória?

Citando o salmo 45, o Abade nos recorda que Deus nos convida a parar e a reconhecer Sua presença amiga sempre conosco: "Parai e reconhecei que Eu sou Deus".

O que significa isso na situação atual? Que podemos vivê-la com liberdade, mesmo que sejamos constritos. A liberdade nem sempre é escolher o que se quer. A liberdade é a graça de poder escolher aquilo que dá plenitude ao nosso coração, mesmo quando tudo nos é tirado. ${ }^{30}$

A parada pode e deve levar-nos a refletir que Deus sempre está conosco, dentro de nós, passando pelas situações difíceis conosco:

Deus entra nas nossas provações, sofre-as conosco e por nós até a morte na Cruz. Assim, revela-nos que a nossa vida, tanto na provação quanto no consolo, tem um significado inteiramente maior do que a resolução do perigo atual. $\mathrm{O}$ verdadeiro perigo que paira sobre a vida moderna não é a ameaça da morte, mas a possibilidade de viver uma vida sem sentido,

${ }^{29}$ LEPORI, M., "Parai e reconhecei que Eu sou Deus", p. 2.

${ }^{30}$ LEPORI, M., "Parai e reconhecei que Eu sou Deus", p. 2. 
de viver sem tender a uma maior plenitude de vida e a uma salvação maior que a mera saúde física. ${ }^{31}$

Por fim, a grande e consoladora mensagem que a Vida Monástica pode deixar para o mundo angustiado e sem esperança é a da existência dos mosteiros. Onde houver uma Comunidade Monástica reunida em oração, ali estará uma parcela da humanidade, um grupo de solitários que buscam viver em comunhão, para testemunhar que é possível viver assim, mesmo no isolamento, e para apresentar a Deus nossa pobreza comum, nossa fragilidade e, ao mesmo tempo, nossa humilde confiança em Deus:

Há uma tarefa que nós, monges e monjas, somos chamados a assumir de modo específico: a oferta de oração, de súplica que implora a salvação. [...] Nossa riqueza é então a pobreza de não ter outro poder senão o de implorar com fé. ${ }^{32}$

Que o Senhor, única riqueza dos monges, nos enriqueça a todos com Seus dons, e nos ajude a descobrir a riqueza da solidão na comunhão neste momento crucial em nossa história.

\section{Referências bibliográficas}

A REGRA de São Bento. Rio de Janeiro: Lumen Christi, 2003.

BAUMAN, Z. Modernidade líquida. Rio de Janeiro: Zahar, 2001.

BÍBLIA de Jerusalém. São Paulo: Paulus, 2003.

COLOMBÁS, G. M. La tradición benedictina: ensayo histórico. Zamora: Ediciones Monte Casino, 1990. (Tomo segundo: los siglos VI y VII).

CONCÍLIO ECUMÊNICO VATICANO II. Constituição Pastoral Gaudium et Spes, sobre a Igreja no mundo de hoje. Disponível em: $<$ http://www.vatican.va/archive/hist_councils/ii_vatican_council/documents/v at-ii_const_19651207_gaudium-et-spes_po.html $>$. Acesso em: 16 nov. 2020.

DANIEL-ROPS, H. A Igreja dos tempos bárbaros. São Paulo: Quadrante, 1991. (Coleção História da Igreja de Cristo, 2).

${ }^{31}$ LEPORI, M., "Parai e reconhecei que Eu sou Deus", p. 3.

${ }^{32}$ LEPORI, M., "Parai e reconhecei que Eu sou Deus", p. 4-5. 
FRANCISCO, PP. Vida após a pandemia. Città del Vaticano: Libreria Editrice Vaticana, 2020.

LEPORI, M. "Parai e reconhecei que Eu sou Deus": Carta do Abade Geral dos Cistercienses, para o tempo da pandemia. Disponível em: $<$ https://caminhocisterciense.com/2020/08/07/carta-pastoral-de-d-maurolepori-para-o-tempo-de-pandemia-ii/>. Acesso em: 16 nov. 2020.

MCKENZIE, J. L. Mundo. In: MCKENZIE, J. L. Dicionário Bíblico. São Paulo: Paulus, 1983.

MERTON, T. Contemplação num mundo de ação. Petrópolis: Vozes, 2019.

NOUWEN, H. J. M. O curador ferido: ministério na sociedade contemporânea. Petrópolis: Vozes, 2020.

NOUWEN, H. J. M. Reaching Out: the three movements of the spiritual life. New York: Doubleday \& Company, 1975.

RADCLIFFE, T. Monges, Vidas Vazias e Beleza. Disponível em: $<$ http://www.triplov.com/ista/escritura/monges.html>. Acesso em: 16 nov. 2020.

ROBERTS, A. Vida Monástica: elementos básicos. Rio de Janeiro: Lumen Christi, 2016.

SÁENZ, A. História da Santa Igreja: do nascimento da Igreja ao Islamismo. Rio de Janeiro: CDB, 2020. t.1.

WOODS Jr., T. E. Como a Igreja Católica construiu a civilização Ocidental. São Paulo: Quadrante, 2008.

Cristiano Holtz Peixoto

Mestre em Teologia pela Pontifícia Universidade Católica do Rio de Janeiro Rio de Janeiro / RJ - Brasil E-mail: cristiano.holtz@gmail.com

Recebido em: 18/11/2020

Aprovado em: 20/05/2021 